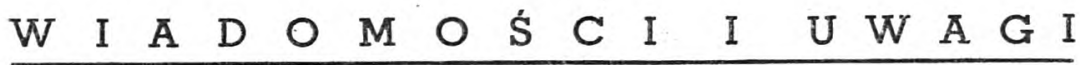

\section{ENCYKLIKA „MUSICAE SACRAE DISCIPLINA“ PIUSA XII}

\section{Słowo wstępne tłumacza}

Acta Apostolicae Sedis ${ }^{1}$ ) z dnia 1 stycznia br. zamieszczają tekst nowej encykliki Papieża Piusa XII ,Musicae sacrae disciplina", ogłoszonej 25 grudnia 1955 r.

Pius XII już po raz drugi podejmuje temat muzyki kościclnej. Po raz pierwszy uczynił to $\mathrm{w}$ encyklice Mediator Dei ${ }^{2}$ ) z 20 listopada 1947 r., w której jednak omawia sprawe uczestnictwa muzyki w kulcie bardzo ogólnie na marginesie zagadnień liturgicznych. Ostatnia encyklika natomiast poświęcona jest w całości i wyłącznie sprawie muzyki kościelnej.

Powody napisania encykliki są następujące:

W ostatnich latach dość często odbywały się międzynarodowe k o n g res y muzyki kościelnej ${ }^{3}$ ). Narady te gromadziły co najwybitniejszych muzyków z całego świata. Szczególne znaczenie miał międzynarodowy kongres zwołany z okazji 900-letniej rocznicy śmierci Guidona z Arezzo. Odbył się on w maju, w jubileuszowym r. 1950. Uczestnicy wskazali na konieczność zredagowania $\mathrm{w}$ formie małego kodeksu wszystkich obowiązujących przepisów prawnych, odnoszących się do muzyki kościelnej, celem łatwiejszego ich poznania i pełniejszego wprowadzenia w życie. Rezultatem tego kongresu był Codex Iuris Musicae Sacrae ${ }^{4}$ ) opracowany przez zasłużonego prawnika rzymskiego F1. Romitę. Kodeks ten nosi charakter prywatnej pracy a nie

1) AAS 48 (1956), 5-25.

2) AAS 39 (1947), 527-595.

3) Pierwszy w Rzymie, maj 1950; drugi we Wiedniu, październik 1954.

${ }^{4}$ ) Monitor Ecclesiasticus 78 (1952), 457-482. 
urzędowego dokumentu. Jednakże wydanie tego rodzaju kodeksu wskazuje na nurtujące wśród muzyków kościelnych tendencje, które zmierzaja do ściślejszego sformułowania i w konsekwencji dokładniejszego wprowadzenia w życie rozporządzeń Stolicy Apostolskiej. Tym tendencjom i życzeniom zadóść czyni niniejsza encyklika.

Drugim powodem, który skłonił Papieża do napisania encykliki, była c h ęć n a ś w i e t 1 e n i a na nowo stanowiska Kościoła względem istniejących przepisów prawno-muzycznych, autorytatywnie sformułowanych w Motu proprio Piusa X i w późniejszych dokumentach. Nowe czasy rodza nowe problemy. Dzisiejsze życie Kościola, w obecnych warunkach, stworzyło nowe potrzeby na całym świecie, zarówno w krajach od wieków chrześcijańskich jak i w krajach misyjnych. I tym potrzebom musi również sprostać muzyka kościelna.

Niezmiernie ciekawie przedstawia się druga część encykliki. Zostały w niej poruszone myśli albo zgoła nowe, dotąd nie omawiane w żadnym z dokumentów Stolicy Apostolskiej, albo zaledwie dotknięte w ,Mediator Dei“. Do nich należy przede wszystkim skomplikowane i trudne zagadnienie t w ó r c z oś c i a r tys t y c znej, a od właściwego rozwiązania tego zagadnienia zależy cała wartość tworzonych na usługi kultu dzieł.

Pius XII jasno określa stanowisko Kościoła. Kościół nie wtrąca się w samą robotę, w samo rzemiosło artystyczne. Nie rości sobie prawa wkraczania do warsztatu artysty. Daje tylko ogólne wytyczne, by one uchroniły twórczość religijną od błędów mogących ją pozbawić należnego przymiotu szlachetności.

Błędy, których dopuszczają się twórcy, wynikają przede wszystkim z ich postawy do samej sztuki jako takiej.

Estetyzujące wyłącznie stanowisko, dążenie do całkowitego wyłączenia sztuki spod jakichkolwiek wpływów, prowadzi w rezultacie albo do eksperymentatorstwa albo do pozbawienia jej "wszelkiego religijnego pierwiastka". Przesadna niezależność twórcza, wyznawanie hasła ,,sztuka dla sztuki“ — jest nieuzasadnione i wręcz obrażające Boga.

Twórczość artystyczra nie może być niczym nieskrępowanym działaniem, samym tylko wyżyciem się artysty, ale musi 
się liczyć - podobnie jak wszelka ludzka działalnośc - z Bo-giem, celem ostatecznym. Bóg, jako pełnia harmonii i piękna, ma być niejako odkrywany w dziełach sztuki. I każde dzieło sztuki stoi w jakimś stosunku do Boga, celu ostatecznego. Dopiero ta zgodność, to odnoszenie się do nieskończonego piękna Bożego, zadecyduje o wartości dzieła sztuki, a tym więcej o wartości dzieła religijnego.

Muzyka zajmuje uprzywilejowane stanowisko wśród wszystkich sztuk. Decyduje o tym jej bezpośredni udział w ceremoniach kościelnych; jej bezpośrednia współpraca z liturgią.

Pius XII, wychodząc $z$ takiego punktu widzenia, wyprowadza d w a wni o ski. Artysta - ateista, względnie chrzéścijanin nie praktykujacy, duchowo oddalony od Boga, nie powinien tworzyć dzieł religijnych. „Brak mu bowiem jakby owego wewnętrznego wzroku, przy pomocy którego dojrzałby czego wymaga majestat boży i kult boży“. I chociażby dysponował znakomicie opanowanym rzemiosłem, nie nada swym dziełom religijnego namaszczenia, religijnego przekonania. I dlatego dzieł jego nie należy w kościele produkować. Artysta zaś wierzący powinien swą sztukę traktować ,jakby kult religijny“. Ma dawać w swych dziełach pełny wyraz swym przekonaniom. A siła jego wiary - pobudzi wiarę wiernych.

Nasuwa się tu samorzutnie analogia do poglądów i postawy, jaką zajmował względem muzyki J. S. Bach, według którego każda sztuka, nawet świecka, musi być potraktowana jako służba boża, jako religja ${ }^{5}$ ).

Stanowisko Kościoła względem chorału gregorians ki e g o, które sprecyzował św. Pius X w Motu proprio pozostaje w omawianej encyklice niezmienione. Uprzewilejowana pozycja śpiewu gregoriańskiego wynika nie tylko z faktu 20-to wiecznej praktyki. Papież dostrzega w nim artyzm najwyższej rangi; artyzm zdolny poruszyć najwybredniejszy smak muzyków i stać się źródłem natchnienia dla kompozytorów.

Nadal pozostaje $\mathrm{w}$ mocy przepis zawarty w Motu proprio ${ }^{6}$ ),

5) Por. A. Schweitzer, J. S. Bach, p. 153.

*) ..Itaque vetus gregorianus cantus traditione perceptus late in Sacris restituendus est" (Motu proprio, 3). 
aby dążyć do wciągania wiernych i chórów kościelnych do wykonywania gregoriańskich śpiewów liturgicznych. Przyczyni sie to do jedności i powszechności Kościoła.

Pewną nowość stanowi udzielenie Ordynariuszom władzy by tam, gdzie panuje niepamiętny zwyczaj (jak u nas w Polsce) ,podczas uroczystej Ofiary Eucharystycznej po odśpiewaniu części liturgicznych w języku łacińskim, wolno było śpiewać pewne utwory w języku ojczystym" ${ }^{\top}$ ). Encyklika nie zezwala jednak śpiewać w języku narodowym samego tekstu liturgicznego. Muszą o tym pamiętać zarówno duchowni jak i świeccy muzycy kościelni, którzy kierując się najlepszymi zamiarami rozbudzenia zamiłowania do śpiewu gregoriańskiego, podstawia ją pod melodie gregoriańskie tłumaczenia polskie.

W hierarchii wartościowania rodzajów muzyki, uprawianych w Kościele, na drugim miejscu stoi polifonia w stylu $\mathrm{Pa}-$ lestriny i jego szkoły. Pod jej adresem Papież wypowiada słowa najwyższego uznania.

Przychylne stanowisko zajmuje również Pius XII wżglẹdem muzyki współczesnej. Jeszcze w Motu proprio (n 5), Pius X - mając na myśli upadek muzyki kościelnej w XIX w., panoszenie się stylu operowego i dramatycznego - szczególnie silnie zaakcentował niestosowność posługiwania się w kompozycjach kościelnych tego rodzaju stylem teatralnym. Pius XII, nawiązując do ogólnie sformułowanej zasady w Motu proprio o popieraniu rozwoju sztuki ${ }^{8}$ ), zarówno w Mediator Dei jak i w omawianej encyklice Musicae sacrae disciplina otwiera bramy Kościoła dla muzyki nowcczesnej pod warunkiem, że spełni ona wymagania kościelnego prawodawstwa muzycznego.

To sięgające w przyszłość stwierdzenie stwarza podstawę dla dalszej twórczości współczesnych kompozytorów. Nie jest też

7) Por. Motu proprio 8, które zezwalało zgodnie ze starym zwyczaj $₫$ rzymskim śpiewać na sumie po Benedictus motet o Najśw. Sakramencie. Podobnie wolno było, po odśpiewaniu przepisanego offertorium mszalnego, wykonać jakiś krótki motet z tekstem aprobowanym przez Kościół.

3) ..Kościół... cenił zawsze postęp sztuki i sprzyjał mu, dopuszczając - przy zachowaniu prawa liturgicznego - do użytku religijnego wszystko co umysł ludzki dobrego i piẹknego w ciạgu wieków wynalazł" . (Motu proprio, 5), 
chyba dla nikogo tajemnicą, że nowoczesna w swych założeniach muzyka kościelna jest bliższa duchowi chorału gregoriańskiego, aniżeli 19-towieczne romantyczne kompozycje. Oczywiście potrzeba rzetelnego talentu, by stworzyć wartościowe dzieła nowoczesnej sztuki. I dlatego Papież przestrzega przed miernota i nieudolnymi próbami ${ }^{9}$.

Papież w encyklice Musicae sacrae disciplina poświęca stosunkowo dużo miejsca - jak w żadnym innym dokumencie Stolicy Apostolskiej - religijnym pieśniom nalrodow y m i zachęca do troskliwego pielęgnowania tego gatunku muzyki kościelnej. W pieśni ludowej tkwią niedość wyzyskane wartości. Ma ona nie tylko przyczynić się do podniesienia przepychu różnego rodzaju nabożeństw pozaliturgicznych. Należy posługiwać się nią nie tylko jako znakomitą pomoca pedagogiczną przy-nauce religii, ale ma ona także stanowić przeciwwage do opanowujących młodzież pieśni świeckich, które ,,czy to ze względu na nieodpowiednią melodię, czy też na słowa, często zdrożne i rozwiązłe, stanowią niebezpieczeństwo dla młodzieży chrześcijańskiej“. Młodzież kocha pieśń! Śpiewa, gwiżdże lub nuci jej melodie. Ileż jednak przyšwaja sobie tandety! Ile błahych tematów zaprząta jej fantazję!

Ten naturalny pociąg młodzieży do pieśni Papież pragnie nasycić katolickimi pieśniami, które ,rodzą czyste i niewinne zadowolenie, a które jednocześnie podsycają i zwiększają wiarę i pobożnośćc. Taki jest pożytek i apostolskie zadanie religijnej pieśni.

Jak natomiast zapatruje się Encykllika na używanie pieśni ludowej podczas nabożeństw liturgicznych?

Dotychczasowe przepisy zakazywały śpiewu ludowego pociczas uroczystych obrzędów liturgicznych. Co więcej Stol. Apost. dążyła i dąży do zainteresowania ludu melodiami gregoriariski$\mathrm{mi}^{10}$ ). Pius XII w Mediator Dei jak i w omawianej encykilice

$\left.{ }^{9}\right)$.,Trzeba jednak zwrócić uwage na to, ażeby tam gdzie zdolność i biegłość nie są wystarczające do tak wielkich pọczynań, wstrzymano się raczej od tak odpowiedzialnych wysiłków, aniżeli tworzono dzieła miniej godne kultu bożego i świętych obrządków“.

10) Por. Motu proprio, 3; Divini cultus sanctitatem, IX. 
nadal utrzymuje stanowisko Kościoła, wzbraniające podczas Mszy uroczystej śpiewów ludowych. Jednakże podczas .mszy nieuroczyście odprawianych wierni moga śpiewać pieśni ludowe. A nawet Papież zachęca do ich pielęgnowania, wskazując na ich przystosowanie się do psychiki narodowej, na czynry przy ich pomocy udział ludu we Mszy. św., na silne oddziaływanie pieśni na rozbudzenie religijnych uczuć wiernych.

Ażeby jednak propagowanie śpiewu ludowego przyniosło właściwe rezultaty Papież zwraca uwage na zalety jakimi mają się te pieśni odznaczać. Uwagi te powinni sobie wziąc do serca kompozytorzy, dyrygenci i organiści, pracujący nad powiększeniem repertuaru naszej polskiej pieśni religijnej.

Pieśń religijna powinna przede wszystkim wyrażać prawdy wiary, uzmysławiać je i tłumaczyć. Melodię i język pieśni ma cechować prostota. A wreszcie pomimo, że pieśni te są małe w rozmiarach nie może im zbywać na powadze i namaszczeniu religijnym. Należy baczyć, by ściśle przestrzegano u nas wskazówek zawartych w Encyklice. Zniknęłyby bezpowrotnie liczne pobożne kicze, sentymentalne piosenki duchowne, pseudopoetyckie pịeśni nabożne, których wiele jeszcze zaśmieca bogaty skarbiec polskich śpiewów kościelnych.

Papież zwraca uwage jeszcze na jeden moment. Moment często niedoceniany przez organistów czy chóry kościelne. Chodzi mianowicie o dobór pieśni, odpowiadający poszczególnym częściom Najświętszej Ofiary. Celowe dostosowanie pieśni pod względem ich treści do różnych części mszy św. odpowiada w pełni duchowi liturgii. A zatem posługiwanie się tzw. ,,mszami polskimi“ idzie po linii wytycznych Encykliki.

Pod koniec swego orędzia Pius XII zamieszcza w s k a z a n i a praktyczne. Nie wnoszą one nic nowego. Poruszają te same myśli, które zapoczątkowało Motu proprio Piusa X i Konstytucja Apostolska Piusa XI Divini cultus. A więc chodzi o za-kładanie przy katedrach wzorowo prowadzonej Szkoły Karitcrow, o fachową naukę śpiewu i muzyki kościelnej po seminariach diecezjalnych czy zakonnych. Chodzi o zawodowe kształcenie muzyczne uzdolnionych kleryków, o zorganizowanie referatu dla spraw muzycznych przy kuriach biskupich jako organu do... 
radczego; czy wreszcie o zakładanie i popieranie istniejących towarzystw muzycznych krzewiących kulturę muzyczną na terenie Kościoła.

Wśród tych uwag uderza nas złagodzone ustosunkowanie się Stolicy Apostolskiej do chórów mieszanych, złożonych z mężczyzn i kobiet. Motu proprio Piusa X wyklucza niewiasty od udziału w chórach ze względu na ich liturgiczny charakter ${ }^{11}$ ). Divini cultus Piusa XI nie formułuje wyraźnie tego zakazu, ale wynika on niedwuznacznie $z$ zaleceń Papieża, by zakładano i utrzymywano chóry męskie tzw. capellae musicorum, na wzór dawniej istniejących w celu wykonywania śpiewów polifonicznych. Do polifonii używać należy sopranów chłopięcych ${ }^{12}$ ).

W oparciu o doświadczenia duszpasterskie, o praktykę wśród różnych narodów - na co wyraźnie powołuje się Papież Pius XII zezwala, aby tam gdzie nie łatwo będzie stworzyć chór chłopięco-męski ,,tekst liturgiczny na mszy uroczystej mógł być śpiewany r.rzez zespół złożony z mężczyzn i kobiet albo panien w miejscu wyłącznie na to przeznaczonym, a położonym poza chórem".

Ogólne omówienie encykliki Musicae sacrae disciplina dowodzi, że nie stanowi ona jakiejś reformy. Co prawda zakres poruszanych przez nią spraw jest szeroki, obejmuje on całokształt zagadnień związanych z muzyką kościelną. Nie można także pominąc faktu rozciągnięcia jej mocy obowiązującej na ryty wschodnie i tereny misyjne. W istocie jednak znaczenie wydanej encykliki polega na uchwyceniu problemów dnia dzisiejszego; na nowym, współczesnym naświetleniu zadań stojących przed muzyką kościelną. Polega na zaapelowaniu i rozbudzeniu zapału w całym katolickim świecie dla spraw muzycznych w oparciu o ścisłe przestrzeganie wytycznych Stolicy Apostolskiej.

11) Motu proprio, 13.

12) Divini cultus, V i VI 